\title{
Criminal Law and Neuroscience: Theory and Practice in the Italian Perspective
}

\author{
Ciro Grandi
}

Department of Criminal Law, University of Ferrara, Italy

\begin{abstract}
The debate on the impact on criminal justice of the empirical evidence offered by techniques of brain exploration and behavioral genetics shows no sign of diminishing, fed by literature now boundless and by case law in constant growth. In the Italian system, the impact of neuroscience at trial is still rather limited and substantially confined to its sedes naturalis, that is to say, the insanity defense. Even in this area, however, there is a very cautious, if not sometimes distrustful, attitude on the part of the courts, still doubtful about the epistemological reliability of neuroscientific evidence. The interdisciplinary dialogue is called upon to help overcome uncertainties and resistance, to avoid the underestimation of data endowed - albeit in a complementary and integrative function - with an increasingly objective value.

Summary: 1. Foreword. - 2. Neuroscience: an outline. - Neuroscience and criminal law in the light of the radicalrevolutionary model. - 4. Neuroscience and criminal law in the light of the moderate-compatibilist model. - 5. An overview of the use of "neuroscientific evidence" in practice - 6. Neuroscience and the evaluation of criminal capacity: a first assessment. - 7. The (still) limited impact of neuroscience in the Italian criminal trial. Diagnosis and prognosis. -8. Conclusions.
\end{abstract}

Keywords: Compatibilism, Forensic Neurosciences, Criminal Capacity, Insanity Defense, Neuroscientific evidence, Italian Case-law.

\section{FOREWORD}

Fifteen years have passed since the publication of the renowned essay by Green and Cohen, according to whom as far as the law is concerned, "neuroscience changes nothing and everything" (Green and Cohen 2004). This oxymoronic title continues to provide a telling picture of the liveliness of the scientific, philosophical, and juridical debate on the potential effects of the recent tumultuous acquisitions of neuroscientific disciplines on the law.

After all, at the same time, the American Association for the Advancement of Science - the most accredited interdisciplinary scientific society at a global level, as well as publisher of Science - has fostered a continuous dialogue between neuroscience, behavioral genetics, and social sciences, including legal disciplines. Within the latter, criminal law has been the most intensely involved sector (Garland and Frankel 2006), due to the particular importance assumed, in the criminal law perspective more than in any other branch of law, by the psychological dimension of human behavior.

The fertility of this dialogue has been illustrated not only, and not so much, by the now uncountable scientific contributions that - first in the North American context (Coppola 2021; Morse 2017; Morse and

*Address correspondence to this author at the Department of Criminal Law, University of Ferrara, Italy; E-mail: grncri@unife.it
Roskies 2013), then in Europe (Demetrio Crespo and Maroto Calatayud 2013; Demetrio Crespo 2017; Demetrio Crespo 2020), and, especially, in Italy (Bianchi et al. 2009; Bertolino 2009; Di Florio 2020; Grandi 2016; Santosuosso 2009) - discuss the legitimacy of the use of neurobiological data in criminal proceedings. But also, and above all, it has been confirmed by the spread of the first statistical surveys on these effects as they have unfolded in criminal proceedings in a plurality of national legal systems (Iran, Alimardani 2018; England and Wales, Catley and Claydon 2015; Canada, Chandler 2015; The Netherlands, De Kogel and Westegeest 2015; USA, Farahany 2015; Australia, Mc Cay and Ryan 2018; Switzerland and France, Moulin et al. 2018; more in general, also with reference to non-criminal domain, Simpson 2012; Spranger 2012).

This paper aims to outline the debate on the impact of recent neuroscientific acquisitions on criminal justice, with a special focus on Italy. It should be pointed out from the outset that these consequences have a very variable scope, depending on which of the two distinct descriptive models of the interactions between criminal law and neuroscience prevails. These two models may be defined, respectively, as the radical-revolutionary model and as the moderate-compatibilist model. Before briefly outlining the empirical premises and consequences of these opposite models, it is worth spending a few words on the meaning of the term "neuroscience". 


\section{NEUROSCIENCES: AN OUTLINE}

A complete reconstruction of the object, methods and empirical results of the wide range of knowledge related to the term "neuroscience" lies beyond the scope of this contribution.

It is therefore sufficient to recall that the term in question covers a heterogeneous group of scientific disciplines, with the common task of explaining how neuronal connections supervise the performance of all human activities: not only simple bodily movements but also those that are more complex (i.e. volition, emotions, formulation of moral judgments), traditionally attributed to the domain of the "mind" and considered in the past inaccessible to experimental investigation. More precisely, in the wide range of neuroscientific disciplines, it is behavioral neuroscience that deals with "brain mechanisms [...] concerned with the specific perspective of behavior, in its sensorimotor, cognitive and emotional manifestations"; while cognitive neuroscience, which partly overlaps with behavioral neuroscience, has the task of investigating "the neural bases [...] of the so-called 'mental' processes, of high level (perception, action, language, reasoning and executive functions, memory)" (Basile and Vallar 2017; on this topic, more in general Gazzaniga et al. 2018).

Neuroscientific studies make use of "brain exploration techniques" (such as electroencephalogram, CT, structural and functional magnetic resonance imaging, etc.), which are the outcomes of a technological evolution spanning several centuries, aimed primarily at satisfying medical-diagnostic needs. These techniques are capable of decoding and measuring, through the use of equipment outside the skull and with reduced margins of approximation, specific signals of different nature - namely electrical, magnetic, radioactive, spontaneous, or induced from the outside - all related to the properties of brain tissue as well as micro-physiological activities located there during the performance of any human action.

Now, the increasingly detailed mapping of these activities during the elaboration of thoughts and decisions has fostered the construction of the two aforementioned models concerning the relationship between criminal law and neuroscience.

3. NEUROSCIENCE AND CRIMINAL LAW ACCORDING TO THE RADICAL-REVOLUTIONARY MODEL.

In line with the radical-revolutionary model, some neuroscientific experiments appear to have provided empirical evidence of the inexistence of free will and the full dependence of human actions on the causal laws of physics. We are referring to the controversial experiments carried out by Benjamin Libet (Libet et al. 1983), later repeated in an updated version by John D. Haynes (Haynes et al. 2007), which appears to describe how every human action is preceded (and not followed, as the "folk psychology" believes) by an unconscious brain activation, independent from any voluntary impulse

According to the so-called "neuro-reductionist" approach, thoughts, emotions, decisions, and consequent behaviors are nothing else other than the output of neuronal processes, without any room left, if not in the field of purely metaphysical speculation, for notions such as "mind", "consciousness", "soul", "conscious will", "free will" (Wegner 2002).

Following the drastic interpretation of this approach, these experimental results can directly affect criminal justice, leaving no plausible alternative to a comprehensive re-foundation of criminal law. In other words, individual liability based on the traditional concept of "guilt" is not scientifically sustainable in a world governed by determinism. The legal concepts of criminal capacity and insanity would also have to be set aside since the very distinction between subjects "normally" capable of self-determination and incapable subjects are unfounded. To this respect, it is worth recalling that "criminal capacity" is a "fundamental requirement of a crime [...] It is a precondition of criminal liability that the defendant is a person with sufficient capacity to be held responsible, and this leads to an examination of infancy and insanity as barriers to criminal responsibility" (Horder 2016). In this paper, "criminal capacity" is used as roughly corresponding to the Italian doctrine of "imputabilità", pursuant to Arts. 85 and ff. of the Italian Criminal Code (infra par. 6).

Furthermore, the sanctioning system hinging on the traditional understanding of retributive punishment should be overcome, and security measures aimed at correction, or subordinately at neutralization, should be preferred instead (Grandi 2016).

Conclusions so radical could not but provoke harsh critical reactions, also in the Italian debate, some of which seem to have hit the mark. As it is impossible to go into more detail, we limit ourselves to pointing out that already in the scientific literature there is no agreement on the suitability of the neuroscientific 
experiments to demonstrate anything regarding the individual's capacity of self-determination. From this point of view, it is sufficient to quote verbatim Ugo Fornari, the author of the most popular Italian text on forensic psychiatry (Fornari 2021), according to whom «no psychodynamic theory, as well as no neuroscientific evidence, has so far been able to reach an objective verification of the existence, impairment or absence of human responsibility and freedom» (Fornari 2017).

Authoritative criminal law literature, at the same time, excludes that sectorial scientific speculations, and controversial ones, maybe automatically transferred in the field of law, with the effect of distorting the consolidated model of criminal responsibility (for an overview Basile and Vallar 2017). All the more so when one considers how this model is not any more rooted in the assumption of free will, understood as absolute freedom of choice. Instead, criminal responsibility is since decades generally based on the less challenging assumption of the "normal" capacity for selfdetermination of the individual, notwithstanding many inescapable biological and social conditioning factors (Di Giovine 2014).

Although these replies are shared by the vast majority of criminal law scholars and boast supporters also in the scientific literature (Morse 2107), the debate on the earthquake that could (or should) shake the traditional framework of criminal responsibility once the neuroscientific discoveries are "taken seriously" still seems far from being exhausted.

\section{NEUROSCIENCE AND CRIMINAL LAW ACCOR- DING TO THE MODERATE-COMPATIBILIST MODEL}

In line with a second and different model, which can be qualified as "moderate-compatibilist", the dilemma of free will falls outside of the area of investigation of neuroscience, since it is a mere philosophical and metaphysical issue. Therefore, once reaffirmed the assumption of the "normal" capacity of selfdetermination as a prerequisite of criminal responsibility, the contribution of neuroscience at the criminal law level should rather focus on the solution of practical problems, within the criminal proceedings. For instance, the assessment of certain mental states can affect in multiple ways the application of criminal law concepts, both at the substantive and procedural level: first of all criminal capacity (both in terms of insanity, and in terms of infancy, i.e. immaturity of the juvenile offender), but also the psychological element (i. e. mens rea) of the offence, as well as the social dangerousness, the individual response to treatment and the mental fitness to stand trial (Basile and Vallar 2017; Corda 2016; Sammicheli and Sartori 2009). In a different perspective, some scholars have also emphasized the contribution of neuroscience in the evaluation of the rehabilitative capacity of the punishment (Coppola 2020; Magro 2018).

Hence, the interaction between neurosciences and criminal law is fueled by the results of the number of experiments illustrating above all, through the aid of "neuroimaging", the decisive role of the "frontal lobes" of the brain in the activity of regulation and inhibition of aggressive impulses. Another key element is, correspondingly, the significant correlation between structural and functional deficits of the prefrontal area of traumatic, pathological, or even congenital origin and the onset of violent behavior, as well as the symptomatic statistical recurrence of such deficits among those convicted of violent crimes and among psychopathic offenders (fundamentally Raine and Yang 2009; more recently Palumbo et al. 2018; Raine et al. 2019. In the Italian literature Pietrini and Bambini 2010).

The theories on the (neuro-)biological explanation of criminal behavior, not at all new in the history of criminal law (Raine 2013; in the Italian literature, Musumeci 2012), therefore seem to have found scientific support much more solid than that of Lombrosian speculations. All the more so when one considers the achievements of behavioral genetics, a discipline that studies the possible "genetic basis" of individual predisposition to certain behaviors, including aggressive and antisocial ones. Truth be told, behavioral genetics excludes the existence of a causative allele for criminal behavior. Rather, it indicates how a certain set of chromosomes especially in individuals exposed to victimization during childhood and adolescence - may negatively affect brain circuits that support inhibition of aggressive and violent impulses. In turn, this makes the individual "less able" to control reactions and thus placed in a condition of "genetic vulnerability" to the risk of committing illegal violent actions (Pellegrini 2010; Walsh and Bolen 2012).

In a different perspective, brain exploration techniques seem to promise potentially useful results also about the verification of the reliability of statements made by the witness or the defendant. In particular, these techniques are based on the principle that the 
elaboration of the lie implies different and more complex neurophysiological activities - measurable by particular methods - than the elaboration of the genuine answer; and also on the detectability of "memory traces", that is to say, the "imprints" that the event leaves in the memory of the individual (Sartori and Agosta, 2010, 2013; with strong criticism Gennari 2018; Merzagora Betsos 2014).

\section{AN OVERVIEW OF "NEUROSCIENTIFIC EVIDENCE" IN PRACTICE}

The considerable critical mass of the studies just mentioned has triggered also in Italy a lively debate on the possible use of neuroscience and behavioral genetics in courtrooms. The flourishing also in the national context of the so-called "forensic neurosciences" symbolizes the collaborative dialogue between neuroscientific investigations and criminal law: these disciplines deal with «the suitability of neuroscience theories and methodologies to constitute valid scientific evidence at trial» (Sammicheli and Sartori 2009; Sartori and Zangrossi 2016).

The dispute is certainly not confined to the theoretical level, given that the number of criminal proceedings in which judges are called to deal with allegations centered (also) on "neuroscientific evidence" of mental disorders is constantly increasing. Undoubtedly, the debate in Italy has been fostered by the first criminal proceeding in Europe in which "neuroscientific evidence" - and in particular behavioral genetics - had an appreciable impact, i.e. the renowned 2009 decision of the Court of Appeal of Trieste (Court of Assize of Appeal of Trieste, 18 September 2009, no. 5), followed shortly after by the other leading case decided by the Tribunal of Como (Tribunal of Como, 20 May 2011, no. 536). The behavioral genetic evidence, in the first case, and the combination of brain images and genetic investigations, in the second case, proved to be decisive for the application of the "partial insanity defense" under Art. 89 of the Italian Criminal Code (Collica 2012; Farisco and Pietrini 2012; Sirigiovanni et al. 2016).

The constant increase of cases in which the Italian courts had to deal with claims (also) based on the socalled "neuroscientific evidence" already allows a distinguishing between:

a) proceedings in which such evidence has been used in support of pleas of insanity defense: in addition to the already mentioned leading cases of Trieste and Como, other decisions of the lower courts have awarded some importance to brain exploration techniques for the purposes of the application of insanity defense (Collica 2018; Ferla 2016; Grandi 2016). In the Italian Supreme Court case-law the neuroscientific evidence introduced by the defense has not been considered sufficiently reliable in the majority of the cases (infra, par. 6; Grandi 2019);

b) proceedings in which neuroscientific evidence have been used to argue the lack of the subjective element of the crime (Basile and Vallar 2017; Sammicheli and Sartori 2015);

c) proceedings in which the results of neuroscientific tests have been used to verify the reliability of statements, of the accused or a witness (Gennari 2018; Grandi 2016).

Now, since groups $b$ and $c$ include a small number of cases, concluding would be premature. On the contrary, the significant number of cases in the group a provides for the opportunity to take stock on the use of neuroscience in the evaluation of insanity defense, ten years after the leading case of Trieste (for a general overview of the Italian case-law, Grandi 2020).

\section{NEUROSCIENCE AND EVALUATION OF CRIMINAL CAPACITY: A FIRST ASSESSMENT}

Firstly, it should be underlined that the evidence of brain exploration techniques and genetic investigations presented by the defense has generally been considered admissible. The doubts formulated by criminal law scholars about the compatibility of the evidence in question with certain prohibitions enshrined in the Italian Code of Criminal Procedure have been substantially overlooked in the case law. In particular, the reference is to the prohibitions under arts. 188 and 189 of the Italian Code of Criminal Procedure, which affect methods and techniques capable of influencing self-determination or the moral freedom of the individual; as well as to the prohibition set forth in Art. 220, para. 2, of the Italian Code of Criminal Procedure, which affects expert opinions aimed at establishing the character and personality and, in general, the "psychological qualities" of the defendant not caused by illnesses (Grandi 2019).

Secondly, in all the proceedings a confrontation has arisen between expert witnesses on the existence of mental pathologies and, above all, on their impact on the capacity of self-determination at the time of the 
offence. These are the key elements in the evaluation of criminal capacity under the Italian Criminal Code. As previously mentioned (par. 3), the term "criminal capacity" is used in this paper as a roughly corresponding to the Italian concept of "imputabilità" regulated under Arts. $85 \mathrm{ff}$. of the Italian Criminal Code (It.CrC). In general terms, Art. 85 It.CrC provides that no one may be punished for an act designated by law as an offense if, at the time he committed it, he had not criminal capacity (1); one shall be regarded has having criminal capacity if he has the capacity to understand and to will (2). Art. 88 regulates the insanity defense ("Vizio totale di mente"), which excludes the criminal capacity of anyone who, at the time he committed the act, was, by reason of infirmity, in such a state of mind as to preclude capacity to understand and to will. In its turn, Art. 89 It.CrC regulates the partial insanity defense ("Vizio parziale di mente") as a mitigating factor applicable to anyone who, at the time he commtted the act, was, by reason of infirmity, in such a state of mind as to greatly diminish, without precluding, his capacity to understand and to will; in this case, the author is liable for the offence committed, but the punishment shall be reduced. In both cases, the insanity test is structured in two subsequent logical steps (Bertolino 2009; Fornari 2021). The first step relates to the assessment and classification of mental disorder and the second concerns the relevance of the disorder itself on the cognitive and volitional capacity of the agent. While the first step falls within the exclusive competence of the expert witness, the second step has a hybrid psychological-legal nature. In other words, while it is up to the expert the evaluation of the existence of a disorder capable of affecting the mental capacity of the agent, it is eventually up to the judge to assess whether, in that specific case, the conditions for the application of Art. 88 of the Italian Criminal Code (full insanity) or of Art. 89 of the Italian Criminal Code (partial insanity) exist.

Thirdly, in almost all of the proceedings in question, the defense expert opinions filed in support of the plea for the insanity defense (total or partial) suggested a combination of traditional diagnostic methods (such as clinical interviews, anamnesis, neuropsychological tests) and neuroscientific evidence (i.e. brain exploration techniques, genetic investigation). Almost in no case, therefore, have the defensive pleas been based exclusively on neuroscientific evidence or behavioral genetics. Rather, the structural or functional abnormality or the peculiar genetic makeup of the defendant was presented as a biological marker of the existence and/or gravity of a clinical condition classified among psychoses or personality disorders that could be detected also with traditional methods.

Fourthly, from a purely statistical point of view, it must be acknowledged that the defensive arguments based (also) on the evidence in question have obtained a rather limited positive response and substantially restricted to the lower courts. The reading of the grounds of Italian Supreme Court decisions reveals a widespread caution, if not an outright open skepticism, regarding the epistemological reliability of neuroscientific and behavioral genetics evidence. With respect to the latter, for example, it has been observed that «the genetic basis of the predisposition to impulsive and aggressive actions does not [have] a consolidated scientific basis, so as to consider the same notion part of the sound knowledge of neuroscience» (Supreme Court, sec. I, July 21, 2016, no. 27129). As for the techniques of brain exploration, according to a recent ruling there is no "to date the necessary degree of scientific consensus about the actual interrelationships (and especially about their degree) between [...] morphological and biological aspects and the voluntary component of the conduct» (Supreme Court, sec. I, June 12, 2018, no. 26895; similar observation in Supreme Court, sec. I, November 7, 2012, no. 43021). Truth be told, the decision in question does not fail to envisage future areas of recognition at trial of neuroscientific contributions. Recalling «the authoritative precedent on the impact of scientific progress on criminal trials represented by the Cozzini decision» - i.e. the ruling that accepted in Italy, though revised and enriched, the Daubert criteria: Supreme Court, sec. 4, December 13, 2010, n. 43786 - the need for a «constant verification of the consensus reached by the theories under consideration within the international scientific community is recognized, which does not exclude a priori the usefulness of similar contributions where such a consensus is reached». Nevertheless, in adherence to the main criterion formulated in the Cozzini decision, the Italian Supreme Court upheld the opinion of the Court of Appeal according to which the point of view of the defense was not "confirmed by appropriate scientific consensus about the links that are claimed to exist between the specific abnormality highlighted in the diagnostic examination and the process of will formation» of the agent (for a critical commentary, Grandi 2019).

It is only in a more recent and still isolated decision concerning a case of brutal homicide, with subsequent necrophiliac conduct - that the Supreme Court showed 
a more flexible approach to neuroscientific evidence (Supreme Court, sec. 1, 18 May 2018, no. 11897). Following a major head injury resulting from a car accident, the defendant had shown a marked tendency to aggression and a reduced ability to control sexual impulses. On the basis of the expert opinion, the Supreme Court found that the defendant "suffers from a brain injury [...] and a genetic abnormality that, under certain environmental conditions, can lead [...] to a tendency to aggression" and "to an increasingly severe lack of impulse control [...] of increasing and unstoppable gravity"; factors capable of rendering the defendant at the time of the fact partially "incapable of governing his own will, spoiled by the alleged brain injury", with application of Art. 89 of the Italian Criminal Code ("Partial insanity") and mitigation of the penalty imposed (Basile and Lometti 2019).

\section{THE (STILL) LIMITED IMPACT OF NEURO- SCIENCE IN THE ITALIAN CRIMINAL TRIAL. DIAGNOSIS AND PROGNOSIS}

The grounds of the above-mentioned case-law with the only exception of the latter decision - confirm the «skepticism of judges concerning the intrinsic scientific validity and potential usefulness of neuroscience with respect to questions of strictly legal relevance» (Corda 2013). After all, scientific literature itself has always warned about the pitfalls underlying the inferential procedure that claims to reach, starting from the brain "images" obtained with the techniques in question, sound conclusions about the "normality" of the area of the cortex examined, or of the neuronal activity located there, and - even more so - about individual predisposition to aggression (Roskies 2013).

Now, on the validity of methods of neuroscientific investigation, on the reliability of their results, and the rules for their interpretation the floor can only be given, at least in the first instance, to empirical sciences.

From this point of view, then, it seems that we cannot ignore the endorsement given to the validity of neuroscientific investigations by the Diagnostic and Statistical Manual of Mental Disorders, the latest version of which (DSM-V) contains numerous references to the techniques of morphological and functional exploration of the brain.

Already in the introductory part, where the most important changes compared to the previous version (DSM-IV) are illustrated, it is emphasized that the structure of the Manual itself has been updated taking into account the most recent acquisitions of neuroscience. More precisely, the Manual takes note of the remarkable progress made in the last twenty years in the field of neuroscience, neuropsychology, and brain imaging techniques, which are credited with having identified the «biological markers» peculiar to a plurality of mental disorders. The scientific progress in the fields of cognitive neuroscience, brain imaging, and genetics achieved in the interval of time since the publication of the DSM-IV is defined as «real and durable».

More specifically, neuroimaging examinations are counted among the useful support methods, along with others, for the diagnosis of a variety of diseases or mental disorders. They include schizophrenia, major depressive disorder, post-traumatic brain amnesia, "intermittent explosive disorder" (for the identification of which are called into play not only brain images but also investigations of behavioral genetics), various disorders of the cognitive sphere, associated with neurodegenerative diseases or traumatic events, and others. In summary, the DSM-V acknowledges and supports the extensive medical and scientific bibliography that describes a significant clinical correlation between altered brain regions, structure and/or functioning and psychotic or psychopathological symptoms. In a nutshell, it deals with structural or functional alteration as a marker of mental disorder.

To conclude on this point, although the evaluation of criminal capacity is not limited to the identification of the mental disorder, as it requires further logical steps, the identification of the abnormality remains the first and unavoidable step. Concerning this step, we can now exclude that the contribution of neuroscience, where available, can be automatically labelled irrelevant and scientifically unreliable.

Precisely in this respect the sceptical attitude of the Supreme Court (par. 6) appears open to criticism. If on the one hand neuroscientific evidence was generally admitted in the trial, it was subsequently underestimated in the ascertainment of psychiatric pathologies, as just mentioned first indispensable step for the application of insanity (total or partial) pursuant to Arts. 88-89 of the Italian Criminal Code.

On the contrary, the reliability of neuroscientific evidence enjoy growing consensus in the specific perspective of forensic sciences.

In this perspective, Ugo Fornari expressly includes neuroscientific techniques among those that can be used, together and alongside the more traditional ones, 
within an integrated clinical-forensic model, which is an effective tool in terms of the identification of all the biological, psychological, and environmental factors that may have influenced the criminally relevant behavior (Fornari 2017).

This viewpoint is fully accepted by Italian criminal law scholars.

It is true that in the very first Italian paper on the relations between neuroscience and criminal law considerable diffidence was expressed with respect to the adimssion of brain images in criminal proceedings: in particular, in the wake of the North American literature, Marta Bertolino formulated concerns about the risk that experts in neurotechniques intended to fully displace the traditional methods of psychiatric expertise, despite the numerous uncertainties on the scientific reliability of morpho-functional investigations on the brain; the same Author also pointed out the dangers of misinterpretation of neuroscientific evidence by the judge, lacking the technical knowledge for a sounded evaluation of brain images (Bertolino 2009).

However, these concerns were subsequently relieved. While continuing to highlight the pitfalls of the evaluation of neuroscientific data during the trial, the same authoritative literature has in fact openly acknowledged that such data "seem to have a lot to offer to criminal law, when it comes to questions of criminal capacity, intent and negligence, automatic acts, prognosis of dangerousness, punitive treatment, perjury"; it is then up to criminal law to "know how to take advantage of it while respecting the fundamental guarantees of the person and the cognitive needs of the process" (Bertolino 2015).

Similarly, it has been acknowledged that neuroscientific studies "already provide important insights to better identify the neurological components that potentially underlie mental disorders that affect the capacity to understand and will" (Magro 2019).

Furthermore, Fornari's call for an 'integrated clinical forensic approach' seems to find textbook correspondence in the criminal law literature. While acknowledging the attitude of neuroscience to offer a suitable contribution to the trial, Corda underlines its capacity to provide for a "simple piece of the mosaic", without it being necessary the composition of the entire picture to legitimise such contribution (Corda 2016). Accordingly, in her most recent paper, Bertolino stresses the need of an integrated approach to mental illness, in the framework of which neuroscience does not offer self-standing evidence, but instead provides a "piece of the puzzle", which reinforce the signals of the existence of mental deficits (Bertolino 2020).

Ultimately, despite the variety of approaches of individual scholars, the Italian legal literature suggests neuroscientific data deserve to be - not only admitted in the trial through expert testimony, but also - effectively appreciated among the evidence on the basis of which the insanity test regulated by Arts. 88-89 is carried out. At the same time, criminal law scholars do not underestimate the risk of misuse of neuroscientific data: on the one hand, the interpretation of brain images in the courtrooms remains a very complex issue; on the other hand, the existence of a genetic or cerebral anomaly shall not provide a "monofactorial" evidence of a mental illness, and even less allow a purely neurobiological explanation of the criminal conduct (Bertolino 2020; Merzagora Betsos 2020).

In response to these concerns, a group of experts in neuroscience have recently addressed and explicitly delimited the role and scope of neuroscientific evidence in the evaluation of criminal capacity. More in detail, they have drafted innovative guidelines aimed at reducing the risks of misinterpretation at trial of the data offered by the techniques of (structural) brain exploration (Scarpazza, Ferracuti et al. 2018). These guidelines, for example, acknowledge the indispensable combination of behavioral diagnosis and neuroimaging, thus reaffirming the complementary and integrative role of the latter for traditional methods of investigation, which cannot be set aside: «Rule number 1. Neuroimaging results should be coupled with behavioural findings». Moreover, the guidelines expressly deny the automatic correlation between brain abnormality and deviant behavior: «Rule number 3 . Not every brain abnormality leads to behavioural symptoms». They also warn about the fallacy of inductive reasoning, which claims to infer the existence of a psychic and behavioral alteration from a brain abnormality, instead of researching the opposite direction, as it should be done: «Rule number 4. Do not reason backwards. To infer the presence of an altered mental state from the presence of brain pathology is a reverse inference. Reverse inferences are a logical fallacy that should be avoided».

These clarifications are all the more significant since they are made, by way of self-restraint, by some of the scholars most frequently involved as an expert witness in the leading cases in the national case-law: "the 
utilization of neuroscientific evidence is not finalized to change the rationale underlying the determination of criminal liability nor challenge the traditional notion of responsibility, but rather to provide a solid and objective complementary contribution to the classical psychiatric assessment that, within the forensic context, suffers from many limitations" (Scarpazza, Pellegrini et al. 2018). It is not suprising, then, that the formulation of these guidelines has been welcomed by legal literature as an appropriate meeting point between scientific knowledge and legal practice (Bertolino 2020; Grandi 2020). After all, their approach confirms what had already been observed years before in the criminal law literature: «neuroimaging does not seek to replace, but rather to join with the traditional techniques of investigation» (Di Giovine 2014; accordingly Corda 2016).

\section{CONCLUSIONS}

Many share the prediction that «cognitive neurosciences will gain more and more relevance at trial» (lacoviello 2016). To avoid an undesirable contrast between "neuromaniac" and "neuroskeptic" approaches, we can only promote a profitable and continuous dialogue between knowledge, based on a twofold awareness.

On the one hand, any abnormalities detectable through neuroscientific investigations do not offer monofactorial explanations, and much less automatic ones, of mental disorders capable of affecting the criminal capacity, but only some pieces of the puzzle, the arduous composition of which is the goal of the psychiatric-forensic evaluation.

On the other hand, the accuracy of this assessment can only benefit from a pluralist epistemological approach, within which the data provided by neuroscience no longer deserve to be underestimated. It seems that these assumptions are already part of the common knowledge of the most up-to-date opinions among neuroscientists and criminal law scholars, which the courts are now also called upon to share.

\section{REFERENCES}

Alimardani, Armin. 2018. "Neuroscience, criminal responsibility and sentencing in an Islamic country: Iran." Journal of Law and the Bioscience 5(3):724-742 https://doi.org/10.1093/jlb/lsy024

Basile, Fabio and Giuseppe Vallar. 2017. "Neuroscienze e diritto penale: le questioni sul tappeto." Diritto Penale Contemporaneo - Rivista Trimestrale (4): 269-289.

Basile, Fabio and Stefano Lometti. 2019. "Assassini nati? Libero arbitrio, genetica comportamentale e neuroscienze in una recente sentenza di Cassazione." Diritto penale e uomo (6): 123-130.

Bertolino, Marta. 2009. "Il breve cammino del vizio di mente. Un ritorno al paradigma organicistico?" Criminalia 3:325-346.

Bertolino, Marta. 2015. II vizio di mente tra prospettive neuroscientifiche e giudizi di responsabilità penale." Rassegna italiana di criminologia 9(2):85-98.

Bertolino, Marta. 2020. "Problematiche neuroscientifiche tra fallacie cognitive e prove di imputabilità e di pericolosità sociale." Diritto penale e processo (1): 42-43.

Bianchi, Angelo, Guglielmo Gulotta, and Giuseppe Sartori, eds 2009. Manuale di neuroscienze forensi. Milano: Giuffrè.

Catley, Paul and Lisa Claydon. 2015. "The use of neuroscientific evidence in the courtroom by those accused of criminal offenses in England and Wales." Journal of Law and Bioscience 2(3):1-40. https://doi.org/10.1093/jlb/lsv025

Chandler, Jennifer A. 2015. "The use of neuroscientific evidence in Canadian criminal proceedings." Journal of Law and Bioscience 2(3):550-579. https://doi.org/10.1093/jlb/lsv026

Collica, Maria Teresa. 2012. "Il riconoscimento del ruolo delle neuroscienze nel giudizio di imputabilità." Diritto penale contemporaneo (www.penalecontemporaneo.it), 15 February 2012:1-26.

Collica, Maria Teresa. 2018. "Gli sviluppi delle neuroscienze su giudizio di imputabilità." Diritto penale contemporaneo (www.penalecontemporaneo.it), 20 February 2018:1-39.

Coppola, Federica. 2020. "Humanizing Prison through Social Neuroscience. From the Abolition of Solitary Confinement to the Pursuit of Social Rehabilitation". Pp. 187-200 in The Routledge Handbook of the Philosophy and Science of Punishment, edited by F. Focquaert, E. Shaw and B. N. Waller. New York: Routledge. https://doi.org/10.4324/9780429507212-20

Coppola, Federica. 2021. The Emotional Brain and the Guilty Mind Novel Paradigms of Culpability and Punishment. LondonNew York: Bloomsbury. https://doi.org/10.5040/9781509934324

Corda, Alessandro. 2013. "Riflessioni sul rapporto tra neuroscienze e imputabilità nel prisma della dimensione processuale". Criminalia 7:497-533.

Corda, Alessandro. 2016. "La prova neuroscientifica. Possibilità e limiti di utilizzo in materia penale". Ragion pratica 47(2):355379.

De Kogel, Katy and Lizanne Westegeest. 2015. "Neuroscientific and Behavioral Genetic Information in Criminal Cases in the Netherlands." Journal of Law and Bioscience 2(3):580-605. https://doi.org/10.1093/jlb/lsv024

Demetrio Crespo, Eduardo and Manuel Maroto Calatayud, eds 2013. Neurociencias y derecho penal. Nuevas perspectivas en el ámbito de la culpabilidad y tratamiento jurídico-penal de la peligrosidad. Buenos Aires: Editorial B de F.

Demetrio Crespo, Eduardo. 2017. Fragmentos sobre Neurociencias y Derecho Penal. Buenos Aires: Editorial B de F, 2017.

Demetrio Crespo, Eduardo. 2020. "Humanist Compatibilism. A Proposal for Reconciliation Between Neuroscience and Criminal Law". Journal of Organizational Psychology 20(3):117.

https://doi.org/10.33423/jop.v20i3.2944

Di Florio, Mattia. 2020. Colpevolezza, conseguenze sanzionatorie e neuroscienze in rapporto al diritto penale. Pisa: Pisa University Press.

Di Giovine, Ombretta. 2014. "Neuroscienze (diritto penale)". P. 711735 in Enciclopedia del Diritto. Annali. Vol. 7. Milano: Giuffré.

Farahany, Nita A. 2015. "Neuroscience and behavioural genetics in US criminal law: an empirical analysis." Journal of Law and Bioscience 2(3):485-509. 
Farisco, Michele and Pietro Pietrini. 2012. "The Impact of Neuroscience and Genetics on the Law: A Recent Italian Case." Neuroethics 5(3):317-319. https://doi.org/10.1007/s12152-012-9152-x

Ferla, Lara. 2016. "Casi difficili e accertamenti peritali in tema di vizio di mente." Jus-online (2):1-28.

Fornari, Ugo. 2017. "Le perizie psichiatriche tra psicoanalisi e neuroscienze", speech at National Convention of the Italian Society of Forensic Psychiatry (Alghero, May 25-27, 2017) available

https://www.youtube.com/watch?v=bFaDUOZZbNs consulted on December 23, 2021)

Fornari, Ugo. 2021. Trattato di psichiatria forense, 8th ed. Milano: UTET.

Garland, Brent and Mark S. Frankel. 2006. "Considering Convergence: A Policy Dialogue About Behavioral Genetics, Neuroscience, and Law". Law \& Contemporary Problems 69: 101-113.

Gazzaniga, Michael, Richard B. Ivry and George R. Mangun. 2018. Cognitive Neuroscience, 3rd ed. New York: Norton.

Gennari, Giuseppe. 2018. "La macchina della verità si è fermata a Salerno... fortunatamente." Diritto penale contemporaneo (5):5-14.

Grandi, Ciro. 2016. Neuroscienze e responsabilità penale. Soluzioni nuove per problemi antichi? Torino: Giappichelli.

Grandi, Ciro. 2019. "Le persistenti cautele sull'uso della prova neuroscientifica nel giudizio di imputabilità." Giurisprudenza italiana 171(1):177-185.

Grandi, Ciro. 2020. "Neuroscienze e capacità di intendere e volere: un percorso giurisprudenziale." Diritto penale e processo (1):24-30.

Greene, Joshua and Jonathan Cohen. 2004. "For the law, neuroscience changes nothing and everything." Philosophical Transaction of the Royal Society Lond. B 359: 1775-1785. https://doi.org/10.1098/rstb.2004.1546

Haynes, John Dylan, Katsuyuki Sakai, Geraint Rees, Sam Gilbert, Chris Frith and Richard E. Passingham. 2007. "Reading Hidden Intentions in the Human Brain." Current Biology 17:323-328.

https://doi.org/10.1016/j.cub.2006.11.072

Horder, Jeremy. 2016. Ashworth's Principles of Criminal Law. Oxford: Oxford University Press. https://doi.org/10.1093/he/9780198753070.003.0004

lacoviello, Vincenzo. 2016. "Le neuroscienze forensi: un progresso pericoloso." Giornale italiano di psicologia (4):749-754.

Libet, Benjamin, Curtis A. Gleason, Elwood W. Wright and Dennis K. Pearl. 1983. "Time of conscious intention to act in relation to onset of cerebral activity (readiness-potential). The unconscious initiation of a freely voluntary act." Brain 106:623-642.

https://doi.org/10.1093/brain/106.3.623

Magro, Beatrice. 2018. "Neuroscienze e teorie 'ottimiste' della pena. Alla ricerca del fondamento ontologico dei bisogni di pena." Diritto penale contemporaneo (12):171-206.

Magro, Beatrice. 2019. "La mente sana e la mente alterata. Uno studio neuroscientifico sulla capacità di intendere e di volere e sul vizio di mente." Archivio penale (3):1-33.

Mc Cay, Allan Cristopher James Ryan. 2018. "Issues pertaining to expert evidence and the reasoning about punishment in a neuroscience-based sentencing appeal." International Journal of Law and Psychiatry 65:1-7. https://doi.org/10.1016/j.ijlp.2018.11.006

Merzagora Betsos, Isabella, Alfredo Verde, Cristiano Barbieri and Alberto Boiardi. 2014. "Come la mente mente. Un nuovo strumento per valutare la memoria." Cassazione penale (5)1896-1915.
Merzagora Betsos, Isabella. 2020. "Il ruolo delle neuroscienze in relazione alla imputabilità e ai giudizi di predittività." Diritto penale e processo (1): 14-23.

Morse, Stephen J and Adina L Roskies. 2013. A Primer on Criminal Law and Neuroscience: Oxford: Oxford University Press. https://doi.org/10.1093/acprof:oso/9780199859177.001.0001

Morse, Stephen J. 2017. Neuroethics: Neurolaw. Oxford Handbook Online. https://doi.org/10.1093/oxfordhb/9780199935314.013.45

Moulin, Valerie, Caroline Mouchetb, Tessa Pillonelb, G.-M. Gkotsib, Bernard Baertschic, Jacques Gasserd and Benoit Testée. 2018. "Judges' perceptions of expert reports: The effect of neuroscience evidence." International Journal of Law and Psychiatry 61:22-29. https://doi.org/10.1016/j.ijlp.2018.09.008

Musumeci, Emilia. 2021. Cesare Lombroso e le neuroscienze: un parricidio mancato. Bologna: Franco Angeli.

Palumbo, Sara, Veronica Mariotti, Caterina lofrida and Silvia Pellegrini. 2018. "Genes and Aggressive Behavior: Epigenetic Mechanisms Underlying Individual Susceptibility to Aversive Environments." Frontiers in Behavioral Neuroscience 12:1-9. https://doi.org/10.3389/fnbeh.2018.00117

Pellegrini, Silvia. 2010. II ruolo dei fattori genetici nella modulazione del comportamento: le nuove acquisizioni della biologia molecolare genetica. Pp. 69-90 in Manuale di neuroscienze forensi, edited by A. Bianchi, G. Gulotta and G. Sartori. Milano: Giuffrè

Pietrini, Pietro and Valentina Bambini. 2010. "Homo ferox: il contributo delle neuroscienze alla comprensione dei comportamenti aggressivi e criminali." Pp. 41-67 in Manuale di neuroscienze forensi, edited by A. Bianchi, G. Gulotta and G. Sartori. Milano: Giuffrè.

Raine, Adriane and Yaling Yang. 2009. "Prefrontal structural and functional brain imaging findings in antisocial, violent, and psychopathic individuals: A meta-analysis." Psychiatry Research 174:81-89. https://doi.org/10.1016/j.pscychresns.2009.03.012

Raine, Adrian. 2013. The anatomy of violence: The biological roots of crime. New York: Pantheon/Random House. https://doi.org/10.1037/e569292014-001

Raine, Adriane,I Shichun Linga and Rebecca Umbachb. 2019 "Biological explanations of criminal behavior." Psychol Crime Law 25(6): 626-640. https://doi.org/10.1080/1068316X.2019.1572753

Roskies, Adina L. 2013. "Brain Imaging Techniques". Pp. 37-74 in A Primer on Criminal Law and Neuroscience, edited by $S$. Morse and A. Roskies. Oxford: Oxford University Press. https://doi.org/10.1093/acprof:oso/9780199859177.003.0002

Sammicheli, Luca and Giuseppe Sartori. 2009. Neuroscienze giuridiche: i diversi livelli di interazione tra diritto $e$ neuroscienze. Pp. 15-40 in Manuale di neuroscienze forensi, edited by A. Bianchi, g. Gulotta and G. Sartori. Milano: Giuffrè.

Sammicheli, Luca and Giuseppe Sartori. 2015. "Accertamenti tecnici ed elemento soggettivo del reato." Diritto penale contemporaneo - Rivista trimestrale (2):273-286.

Santosuosso, Amedeo, ed. 2009. Le neuroscienze e il diritto. Pavia: lbis.

Sartori, Giuseppe and Sara Agosta. 2010. Menzogna, cervello e lie detection. Pp. 163-192 in Manuale di neuroscienze forensi, edited by A. Bianchi, g. Gulotta and G. Sartori. Milano: Giuffrè.

Sartori, Giuseppe and Sara Agosta. 2013. "The autobiographical IAT: a review." Frontiers in Psychology 4:1-12. https://doi.org/10.3389/fpsyg.2013.00519

Sartori, Giuseppe and Andrea Zangrossi. 2016. "Neuroscienze Forensi." Giornale Italiano di Psicologia (4)689-711. 
Scarpazza, Cristina, Silvia Pellegrini, Pietro Pietrini and Giuseppe Sartori. 2018. "The Role of Neuroscience in the Evaluation of Mental Insanity: on the Controversies in Italy". Neuroethics (11):83-95.

https://doi.org/10.1007/s12152-017-9349-0

Scarpazza, Cristina, Stefano Ferracuti, Alessio Miolla and Giuseppe Sartori. 2018. "The charm of structural neuroimaging in insanity evaluations: guidelines to avoid misinterpretation of the findings." Translational Psychiatry 8:1-10.

https://doi.org/10.1038/s41398-018-0274-8

Simpson, Joseph R., ed. 2012. Neuroimaging in Forensic Psychiatry. From the Clinic to the Courtroom. Oxford: Wiley-Blackwell. https://doi.org/10.1002/9781119968900
Sirgiovanni, Elisabetta, Gilberto Corbellini and Cinzia Caporale. 2016. "A recap on Italian neurolaw: epistemological and ethical issues." Mind and Society 16(1-2):1-19.

Spranger, Tade Matthias, ed. 2012. International Neurolaw: a Comparative Analysis. Berlin:Springer. https://doi.org/10.1007/978-3-642-21541-4

Walsh, Anthony, and Jonathan D. Bolen. 2012. The Neurobiology of Criminal Behavior. Gene-Brain-Culture Interaction. New York: Routledge.

Wegner, Daniel. 2002. The illusion of conscious will. Cambridge MA: Mitpress. https://doi.org/10.7551/mitpress/3650.001.0001

https://doi.org/10.6000/1929-4409.2022.11.01

(C) 2022 Ciro Grandi; Licensee Lifescience Global.

This is an open access article licensed under the terms of the Creative Commons Attribution License (http://creativecommons.org/licenses/by/4.0/) which permits unrestricted use, distribution and reproduction in any medium, provided the work is properly cited. 